\title{
A KAPCSOLATHÁLÓ-ELEMZÉS SZERVEZETI LEHETŐSÉGEI
}

A szerző dolgozatában a szervezeti kommunikáció hatékonyságának, illetve milyenségének mérési, feltérképezési lehetőségét mutatja be a kapcsolatháló-elemzés segítségével. E módszer alkalmazásával olyan jellemzők feltárására van lehetőség, amelyek a szervezeti kultúra kialakításához, javításához nélkülözhetetlenek.

A neves társadalomtudós, Polányi Károly már egészen korán felvetette, hogy a gazdasági folyamatok mélyen a társadalmi folyamatokba ágyazódnak és ezért nem vizsgálhatók a társadalmi kapcsolatok háttere nélkül (Polányi, 1976). Polányi a gazdaságot a társadalom szerves részeként tekinti, a társadalmi-politikai és kulturális összefüggéseitől megfosztott ökonomizmus helyett egy újfajta „gazdasági antropológiát” próbált kidolgozni, amely a személyek társadalmi viszonyainak gazdasági aspektusát vizsgálja, s amely a termelést, a gazdasági tevékenységeket társadalmi folyamatként fogja fel. Így a gazdasági jelenségeket a társadalom egészének, intézményi és kulturális rendszerének öszszefüggéseiben értelmezi.

Ezt a szemléletmódot később a hálózatelemzés atyjaként számon tartott Mark Granovetter egészítette ki. Granovetter három különböző szinten elemezte a gazdasági aspektus általa társadalmi beágyazottságnak nevezett jellegzetességét: az intézményeken túl a gazdasági cselekvések és a gazdasági eredmények beágyazottságát vizsgálta (Granovetter, 1985; 1996). „Beágyazottságon azt értem, hogy a gazdasági cselekvést, eredményeket és intézményeket befolyásolják a cselekvők személyes kapcsolatai és a kapcsolatháló egészének szerkezete. Ezekre a beágyazottság relációs, illetve strukturális vonatkozásaként utalok." (Granovetter, 1996: 65. o.). A granovetteri szemléletmódot és az ebből kifejlődő kapcsolatháló-elemzés eszköztárát a gazdaság számos területének vizsgálatá- ra használják, a piaci folyamatok, intézmények elemzésétől az egyes szervezeteken belüli kommunikációs és egyéb jellegű kapcsolatok vizsgálatáig.

A kapcsolatháló-elemzés olyan területek vizsgálatát teszi lehetővé, amelyekről e módszer nélkül csak sejtéseket fogalmazhatnánk meg, de amelyek lényeges jellemzői egy közösség működésének. A hagyományos adatokkal - az analitikus ismérvekkel, amik a vizsgálat tárgyának mérhető egyedi jellemzői és a kontextuális ismérvekkel, amelyek a környezetre vonatkoznak vagy a környezettel való összevetésre használhatók - szemben a hálózatelemzéskor új típusú, relációs adatokkal dolgozunk. Eme új típusú ismérveket már a hatvanas években bevezette Lazarsfeld és Menzel a tudományos gondolkodásba (Lazarsfeld - Menzel, 1961). A relációs ismérvek a szereplők közti kapcsolatra, a kapcsolatok jellemzőire vonatkoznak. Például, ha egy vezető működését vizsgálom, akkor analitikus ismérvek a vezetőre vonatkozó személyes adatok: iskolai végzettsége, tudományos fokozata, személyiségjellemzők stb. Kontextuális ismérvek a környezetre vonatkozó információk: milyen szervezeti kultúra jellemzi azt a szervezeti környezetet, amiben tevékenykedik, milyen a szervezet felépítése, hol helyezkedik el a hierarchiában a vizsgált vezető stb. A relációs adatok pedig a különböző szervezeti szereplőkkel való kapcsolatát jellemzik: kikkel és milyen gyakran érintkezik, kikkel és milyen információkat oszt meg, milyen a beosztottaival való kapcsolat jellege és domináns iránya, 
milyen mértékű presztízst tükröznek a kapcsolatok, mennyire van centrális pozícióban a vezető stb.

Anthony Dekker a kapcsolatháló-elemzés fôbb céljait négy pontban foglalja össze (Dekker, 2001a; 2001b). A kapcsolatháló-elemzés első célja, hogy az emberek és csoportok közti kommunikációt és egyéb kapcsolatokat vizuálisan megjelenítse diagrammok segítségével. A második célja, hogy tanulmányozza azokat a tényezőket, amelyek befolyásolják a kapcsolatokat és vizsgálja a kapcsolatok közti korrelációkat. A harmadik cél, hogy kivizsgálja a relációs adatokkal kapcsolatos sejtéseinket (például, hol vannak olyan „,szűkületek” a kapcsolatrendszerben, ahol az információk és a munkafolyamatok lelassulnak, vagy az információáramlás csatornáinak „térképe” összhangban van-e az adott csoport formális struktúrájával). És végül negyedik célja, hogy ajánlásokat tegyen a folyamatok javítására, megalapozza a szervezetben, csoportban folyó kommunikáció és munkafolyamatok hatékonyságának fejlesztését.

Hálózatelemzéskor a kapcsolatok jellemzői két szinten vizsgálhatók: mikroszinten és makroszinten. Mikroszinten egy adott szereplő kapcsolathálóját (egohálóját) vizsgáljuk, makroszinten pedig egy adott csoport kapcsolathálójának szerkezetét (Letenyei, 2000).

Mikroszinten a következő kérdéseket tehetjük fel: „egy vizsgált pont (cég, település, személy stb.) egyéni kapcsolathálója mennyire kiterjedt, a háló mintázata mennyire megfelelő (azaz eljut-e ugyanazokhoz a központokhoz, ahová a sikeresebb szereplők), vagy hogy az egyén kapcsolatai mennyire rétegzettek" (Letenyei, 2000: 22. o.), továbbá, hogy az adott szereplő mennyire tölt be centrális pozíciót, mekkora a csoporton belüli presztízse?

Makroszinten pedig a következőket vizsgálhatjuk: „Elég sűrű-e a hálózat? Hol vannak sűrűsödési pontok? Hogyan definiálhatók az egyes hálózati csoportok? Mely pontok töltenek be közvetítő szerepet? Hány lépésben lehet elérni egyes csoportokat, tagokat?" (Letenyei, 2000: 22. o.), továbbá, hogy milyen mintázatokat vesznek fel a hálózatok vagy egyes részeik?

Az előbbiek tulajdonképpen már sejtetik a kapcsolatháló-elemzés hasznosításának legfontosabb szervezeti terepét: a szervezet kommunikációs folyamatainak vizsgálatához járulhat hozzá. A szervezet (vagy csoport) kommunikációs kapcsolatainak feltérképezésére azután épülhet a szervezet működésének újfajta ábrázolása, az organigráf. De a kapcsolatháló-elemzés eredményei, az interakciós formák feltárása a szervezeti kultúráról egyéb kutatással nyert képet is finomíthatják. A továbbiakban illusztrációs jelleggel (és nem tagadom, népszerűsítő szándékkal) eme három területen próbálom érzékeltetni a kapcsolatháló-elemzés erényeit.

\section{Kommunikációs kapcsolatok, interakciós mintázatok}

E módszerrel olyan (fentebb felsorolt) területeket vizsgálhatunk, amelyek a szervezeti kommunikáció hatékonyságát alapvetően befolyásolják, Az ebben rejlő lehetőségeket egy felsőoktatási intézményben végzett kutatásból kiemelt részletekkel illusztrálom. A példa egy tanszék kapcsolathálójának néhány jellemzőjét mutatja be. ${ }^{1}$

A tanszék kapcsolathálójának gráfját mutatja az 1 . ábra. A gráfban a pontok az egyes tanszéki dolgozókat jelölik (akiket csak kezdőbetűkkel jelöltem, kivéve a tanszékvezetôt és a tanszéki titkárnőt), a köztük lévő kapcsolatot pedig nyilak jelzik. A nyilak iránya a kapcsolatok irányát tükrözi. A mindkét irányba mutató nyíl értelemszerűen kétirányú kölcsönös kapcsolatot jelöl. Egy kapcsolatnak az erősségét egyrészt a nyíl vastagsága, másrészt a nyíl melléírt érték mutatja.

A tanszék kapcsolathálójának gráfja

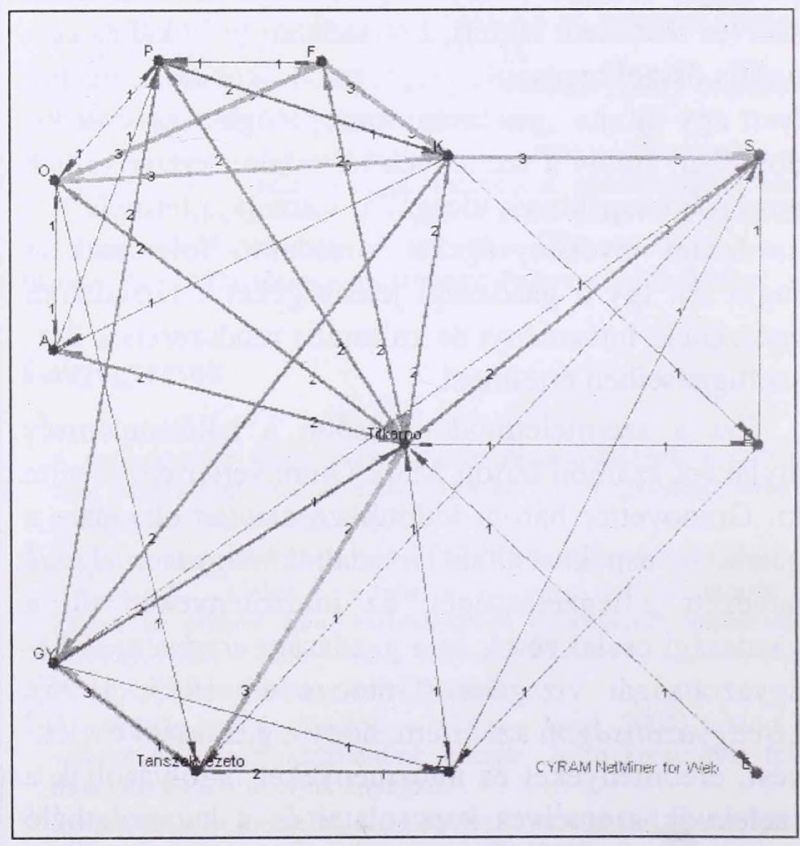

Néhány jellemző a gráfból is látható. Egyrészt láthatjuk, hogy viszonylag nagy a kapcsolatok száma: egy hálószerû mintázatot mutat az ábra. Ezt bizonyítja a kapcsolatháló sűrűsége (network density) is, aminek 
az értéke 0,409. Tehát a létező kapcsolatok a lehetséges kapcsolatoknak közel felét teszik ki, ami elég magas értéknek számít. Vannak ugyan centrális pontok e hálózatban, de ha a látszólag erősebb központot jelentő tanszéki titkárnôt kiemelem (az ő szerepéről később írok), akkor az egyes alanyok kapcsolódásai összességében mégis egy erős, központ nélküli, szabad hálózat képét mutatják.

A teljes hálón belül megfigyelhető egy szorosabb kapcsolatrendszerű csoportosulás az $\mathrm{A}-\mathrm{O}-\mathrm{P}-\mathrm{F}-\mathrm{K}$ személyek között, amit az 1. ábrán be is karikáztam pirossal. Az említett személyek között az átlagosnál jóval sűrübb és erősebb, szimmetrikus kapcsolatokból álló háló „,feszül”.

2. ábra

A csoporton belüli kapcsolatok alapján lehetséges klikkek vizsgálata

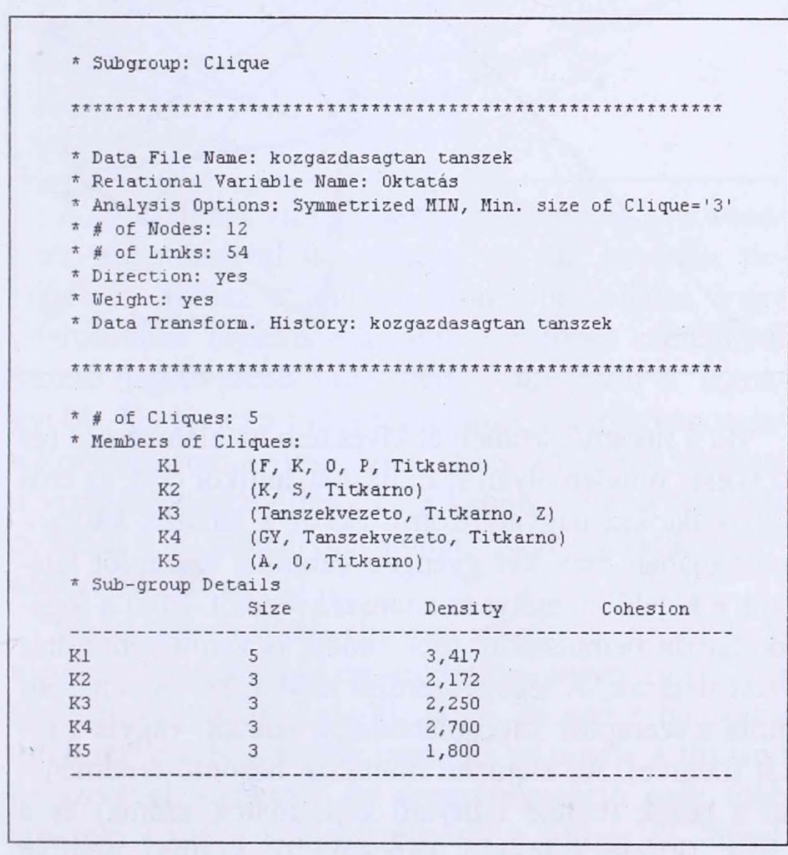

Ezt tïkrözi a lehetséges klikkek (szoros kapcsolatban álló személyek kisebb csoportjai) vizsgálata is. A kapcsolatok kölcsönössége és erőssége alapján öt lehetséges klikk adódik (2. ábra). Láthatjuk, hogy az öt lehetséges csoportosulásból a legerősebb klikk a Kl-es (eme klikk kapcsolatainak a kapcsolatok erősségével is súlyozott sűrűsége a legnagyobb: 3,417), aminek tagjai az F, K, O, P személyek, akik közti szoros hálót bekarikáztam a gráfon. A klikkek statisztikai vizsgálata azonban pontosította a gráf alapján született sejtést, mivel azt mutatta ki, hogy szoros kölcsönös kapcsolat az előbb sorolt F, K, O, P személyek között van, és a sejtés alapján hozzájuk sorolt $\mathrm{A}$ jelű szereplő csak az O szereplővel való szoros kapcsolata által kapcsolódik az előbbi csoporthoz (ez látható a klikkek közti átfedés vizsgálatából is). A második legerősebb klikk a tanszékvezető és a GY szereplő igen szoros kapcsolata. A tanszéken belüli klikkek vizuálisan is megjeleníthetôk (3. ábra). A klikkek gráfján láthatjuk, hogy mely szereplők tartoznak az egyes klikkekhez, illetve, hogy az egyes klikkek mely szereplőkön keresztül kapcsolódnak egymáshoz (az ábrán a zöld csomópontok jelenítik meg az egyes klikkeket).

\section{3. ábra}

A csoporton belüli klikkek gráfja

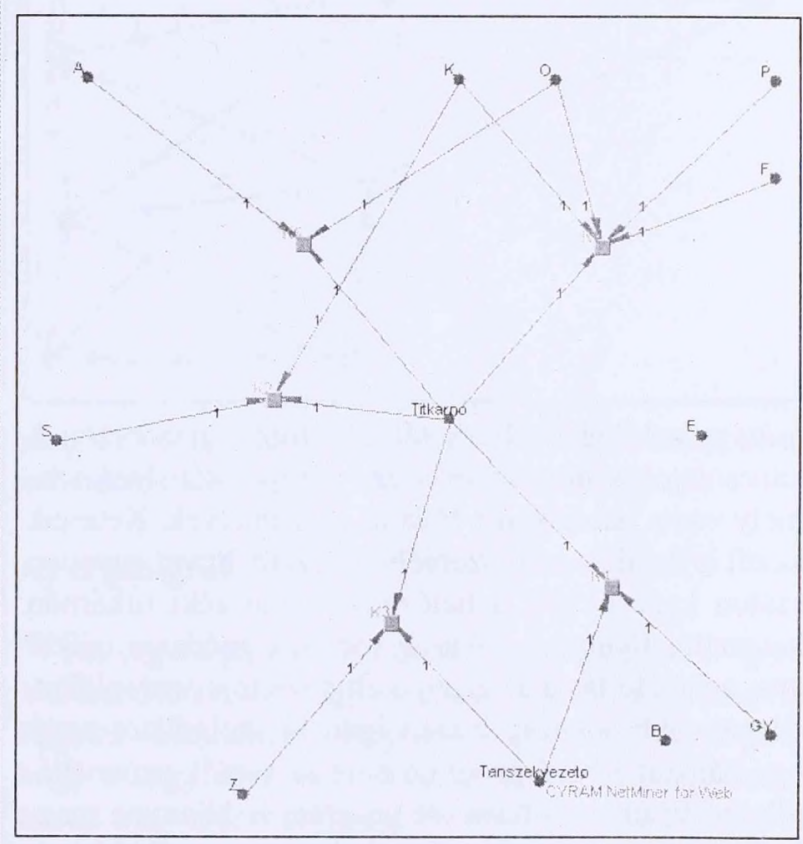

A kapcsolatháló-elemzés segítségével azt is megmutathatjuk, hogy az egyes személyek hány lépésből érhetők el (közeliség - closeness) és hány útvonalon érhetők el (köztesség - betweenness). Bemutató példaként azt vizsgáltam, hogy az $\mathrm{O}$ személy az $\mathrm{S}$ jelű személyt hogyan tudja elérni. Azt az eredményt adta a vizsgálat, hogy a két személy közti legrövidebb utak száma öt (vagyis öt releváns csatornán érhetik el egymást), és a legrövidebb útvonalak közül a legerôsebb kapcsolatokat kihasználó elérési út a $\mathrm{K}$ személyen keresztüli. Az ilyen hálózatelemző szoftverekkel igen gyorsan meghatározható a hálózat egy pontja (jelen esetben egy adott személy) elérésének hatékony kommunikációs útja (olyan nagyobb sokaságok esetében is, ahol a kapcsolatok hálózata nem eredményez ilyen szépen áttekinthető mintázatot).

Ezzel a módszerrel azt is könnyen kimutathatjuk, hogy mely szereplők vannak elszigetelt vagy perifériás pozícióban: azok a személyek, akik kevés útvonalon 
Két szereplő közti legrövidebb út

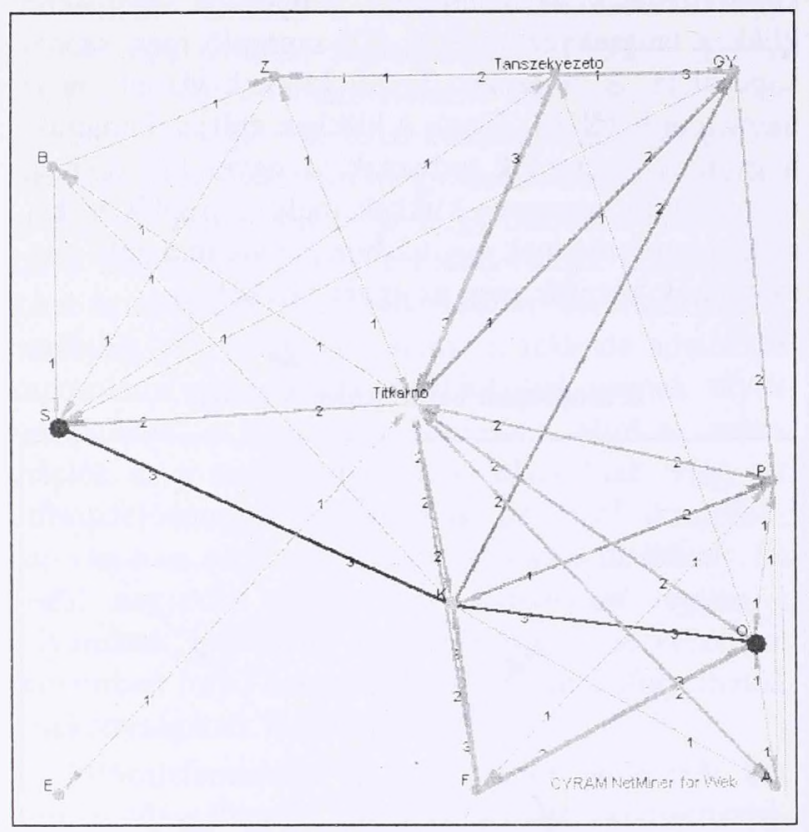

és/vagy sok lépésből érhetők el a többség számára. A kapcsolatok száma és erőssége alapján két ilyen személy van a tanszéken a B és az E személyek. Kettejük közül is kritikus az E személy helyzete, mivel egyetlen szálon kapcsolódik a hálózatra, a tanszéki titkárnőn keresztül. Ilyen kis sokaság esetén e módszer nélkül sem nehéz feltárni az elszigetelt pozíciójú szereplőket, de nagyobb sokaság esetén igen jó szolgálatot nyújt egy hálózatelemző program eme szereplők azonosításához. Az általam használt program is könnyen meghatározta az egyetlen szálon (bridge) kapcsolódó személyt és azt a kritikus pontot, ahol le lehet választani a kommunikációs hálózatról (cutpoint) (5. ábra).

$\mathrm{Az}$ is fontos információ, hogy mennyire vannak központi szereplők a hálózatban. Ezt a centralitás vizsgálatával elemezhetjük. Mielőtt ennek ismertetésébe kezdenék, előtte szeretném a tanszéki titkárnő sajátos pozícióját értelmezni. Már a tanszék gráfjára (1. ábra) pillantva is kitünik, hogy (látszólag) egyetlen centrális pont van a hálózatban: a tanszéki titkárnő, aki mindenkivel kapcsolatban áll. És valóban, a centralitás mutatók egy része is igazolja ezt a sejtést. Azonban az interjúk során kiderült, hogy a tanszéki titkárnővel való kapcsolata a legtöbb tanszéki dolgozónak az adminisztratív előírások miatti kötelezettségeiből adódik, és a tartalmi információáramlás gyakran más szálakon zajlik a tanszéki oktatók között. Ezt alátámasztja az is, hogy a tanszéki titkárnő kapcsolata a többi szereplővel általában gyenge. A legtöbb megkérdezett a tanszéki titkárnő felé való információs kötelezettségét inkább nyűgnek érezte: a tanszéken kialakult részben informális kommunikációs hálóra próbálnak ráerőltetni egy formális, központosított interakciós mintázatot.

5. ábra

Függő helyzetben lévő szereplő

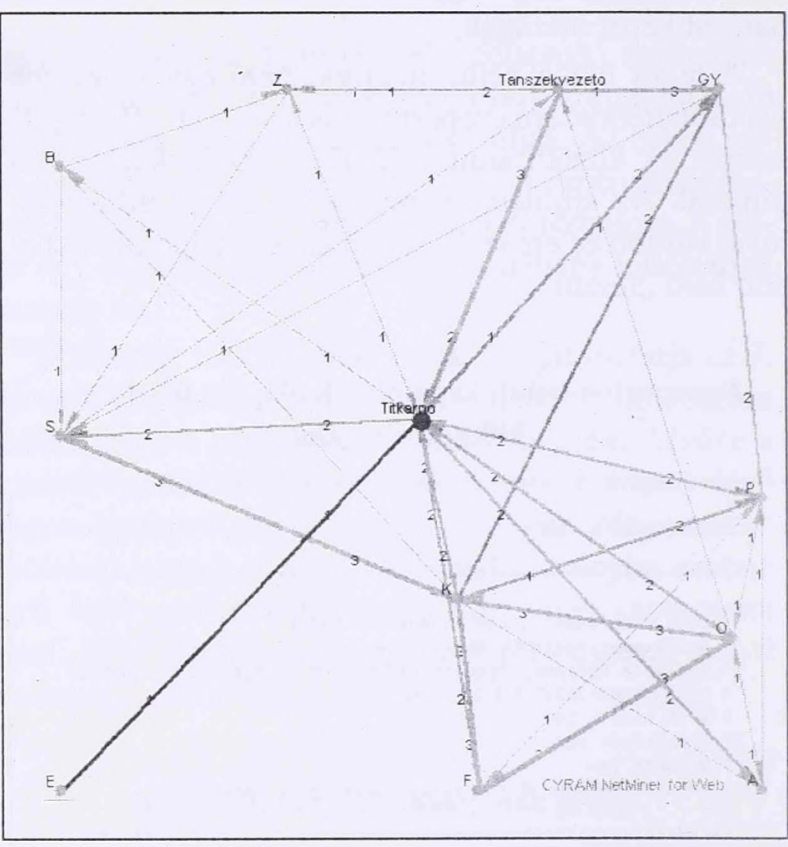

Ha a titkárnő személyét kiveszem az elemzésből (és ki is esik minden olyan számításnál, amikor csak az erős kapcsolatokra hagyatkozom), akkor a tanszék kapcsolathálójában csak két gyengén centrális szereplőt találunk a $\mathrm{K}$ jelű személyt és a tanszékvezetôt. Mint a fogalomtárban bemutattam, több módja is van a centralitás vizsgálatának. A legegyszerűbb módja, ha összehasonlítom a szereplők kapcsolatainak a számát, vagyis a fokát (degree). Az elemzett mintában hasonló eredményt ad a befok (befelé irányuló kapcsolatok száma) és a kifok (kifelé irányuló kapcsolatok száma) alapján végzett számítás. A befok alapján (az első helyen szereplő tanszéki titkárnőn túl) a tanszékvezető, a K, P, O és S személyeknek a legmagasabb a kapcsolataik száma, de az értékek csak nagyon gyenge centralitást tükröznek. A kifok alapján már egyértelműbb képet kapunk: a $\mathrm{K}$ szereplő centrálitását tükrözi. A tanszékvezető kifelé irányuló kapcsolatainak száma elmarad sok más tanszéki dolgozóétól, vagyis a kifok az esetében egyáltalán nem tükröz központi pozíciót. Viszont mutatja a befok és kifok eme jelentôs eltérése a tanszékvezetô kiemelt presztízsét. Ugyanis egy szereplő presztízsét mutatja a befelé és kifelé irányuló kapcsolatok számának, vagyis a befoknak és kifoknak a különbsége. 


\section{6. ábra}

Centralitás a köztesség (betweenness) alapján (csak az erős kapcsolatokat figyelembe véve)

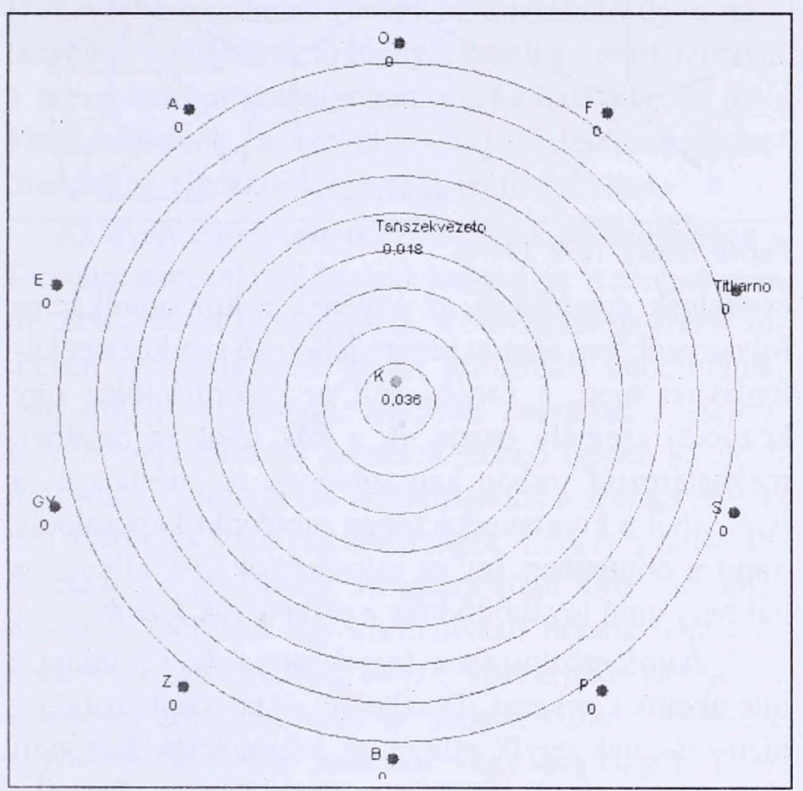

A centralitást vizsgálhatjuk a köztesség (betweenness) számításával is, eszerint az van centrális pozícióban, akihez a legtöbb úton lehet eljutni, vagy pontosabban fogalmazva, akihez a többi szereplőtől vezető legrövidebb utak száma átlagosan a legnagyobb. Ha ennél a módszernél csak az erős kapcsolatokra alapozom a vizsgálatot, akkor a titkárnő kiszorul a vizsgálat horizontjáról és a kapott sorrend centrális pozíciót a $\mathrm{K}$ személynél mutat, majd második a tanszékvezető (6. ábra).

Ha a kapcsolódó elemek számát a kapcsolódó elemek erősségével és centralitásával súlyozva veszem figyelembe, akkor kiderül, hogy az egész hálózatra értelmezve a $\mathrm{K}$ személy centrális pozíciója a titkárnő helyzetével vetekszik és a tanszékvezető csak több tanszéki kolléga után következik a sorban (7. ábra). Összességében tehát, ha a tanszéki titkárnő speciális helyzetét kihagyom a vizsgálatból, akkor csak egy gyenge-közepes centrális szereplő, a K személy adódik, rajta kívül még a tanszékvezető helyzete mutat igen gyenge centralitást. Joggal tekinthetem ezért a tanszék kapcsolathálóját erősebb központ nélküli szabad hálózatnak.

Mindezen eredmények alapján ajánlásokat is megfogalmazhatunk az adott szervezeti egység kommunikációs kapcsolatrendszerének fejlesztéséhez. Kimutatható volt például, hogy mely szereplők szorulnak ki a kommunikációs folyamatokból, hogy kik azok a szereplők, akiknek centrális pozícióját az információk hatékony áramoltatásához ki lehet használni. De az elem-
Az egész hálózatban értelmezett centralitás a kapcsolódó elemek centralitásával súlyozva

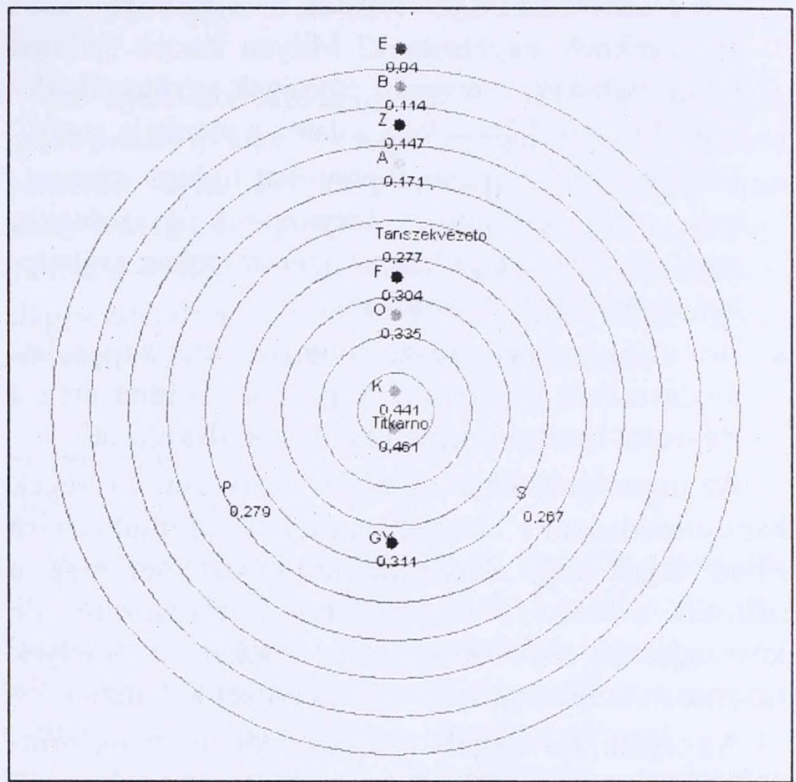

zésből az is látható, hogy a háló mely részei lazábbak a kelleténél, hol érdemes a kapcsolatokat erősíteni.

\section{Az organigráf}

$\mathrm{Az}$ organigráfok a szervezetek müködésének igen érdekes és hasznos megközelítését adják. Mintzberg és Heyden (Mintzberg - Heyden, 2000) azt vetették fel, hogy a hagyományos szervezeti ábrák nem túl hasznosak egy szervezet megismeréséhez, múködésének megértéséhez, mivel nem adnak válaszokat azokra az alapvető kérdésekre, amelyeket egy vállalat működése kapcsán érdemes feltenni: Milyen folyamatok zajlanak a szervezetben? Milyen szervezeti részek kapcsolódnak egymáshoz a tényleges működés során? Kihez, milyen információk, ötletek kell, hogy eljussanak és honnan? Hol vannak konfliktusok a szervezetben? Milyen erősségei vannak a szervezetnek? E kérdések megválaszolásához egy új megközelítési módot javasolnak, amit organigráfnak (a szervezeti ábra francia terminusa alapján) neveztek el. A hagyományos szervezeti ábrák a szervezet formális hierarchiáját tükrözik: a kis négyszögek elhelyezkedése a hatalmi viszonyokat, alá-fölérendeltségeket, a négyszögeket összekötő vonalak pedig a formális utasítási csatornákat és a jelentési kötelezettségek útját írják le. Ezzel szemben az organigráfok a folyamatokon alapulnak. Azt próbálják szemléltetni, hogy hogyan müködik a vállalat, bemutatva az emberek, termékek és információk kölcsönhatásait, fontos kapcsolódásait, összefüg- 
géseit. Ennek alapján olyan kérdésekre kereshetjük a választ, mint:

- Milyen fontosabb folyamatok zajlanak a szervezetben és ezekben mi a feladatuk az egyes szervezeti egységeknek, egyéneknek? Milyen láncok épülnek fel az emberek, szervezeti egységek együttmúködésébőll? Ki kivel kerül kapcsolatba a munkája során?

- Milyen fontosabb csomópontokat tudunk azonosítani, ahol különböző folyamatok összeérnek, amelyek összehangolják az erőforrásokat: embereket, eszközöket, információkat?

- Hol alakulnak ki a résztvevők összetett kapcsolatrendszeréből hálózatok? Vagy hol kívánná meg a folyamat hatékonysága a hálózat kialakulását?

$\mathrm{Az}$ organigráfokban az egyes szervezeti egységek kapcsolódásának, összefüggésének bemutatására Mintzbergék négy alapformát különböztetnek meg: a halmazt, a láncot, a csomópontot és a hálózatot, de lehetségesnek tartanak más ,alakzatokat” is, amelyek hasznosan érzékeltethetik egy szervezet jellemzőit.

Az organigráf megalkotásához pedig hasznos információkkal szolgálhat a kapcsolatháló-elemzés, aminek során a kommunikációs kapcsolatokat, láncokat és csomópontokat lehet feltérképezni. A korábbi példa bemutatásánál láthattuk, hogy e módszerrel feltárhatjuk a centrális pozíciójú szereplőket (csomópontokat), a kommunikációs kapcsolatok láncolatát, a hálózatok „térképét”. Az interakciós kapcsolatok szerkezetéről kapott képet aztán összevethetjük a szervezet egyéb folyamatainak és struktúráinak ábrájával, így az organigráf készítése azt is kikényszeríti, hogy vizsgáljuk a kommunikációs, interakciós mintázatnak és a szervezet egyéb (munka)folyamatainak, valamint felépítésének illeszkedését.

\section{Kommunikáció és szervezeti kultúra}

A szervezeti kultúrát tárgyaló szövegekben vagy előadásokban rendszerint felbukkan a kommunikáció témaköre, hol úgy, mint a kultúra egyik jellemző megnyilvánulása (tehát a kultúra egyik jellemző területe), hol úgy, mint a kultúra működésének, fenntartásának és továbbörökítésének alapvető eszköze. Például a népszerű Handy-féle kultúra tipológia egyik alapja az interakciós, kommunikációs kapcsolatok jellege. Handy külön vizsgálja a szervezetben az interakciók jellemző formáit, mintázatait, ami alapján három morfológiai típust határoz meg (Handy, 1999) (8.ábra).

$\mathrm{Az}$ interakcióminták a szervezeti egyének közti kommunikációs utak szerkezetét mutatják: azt, hogy az információk milyen utakon áramlanak, hogyan kap-
8. ábra

\section{A csoportinterakció alapvető formái}

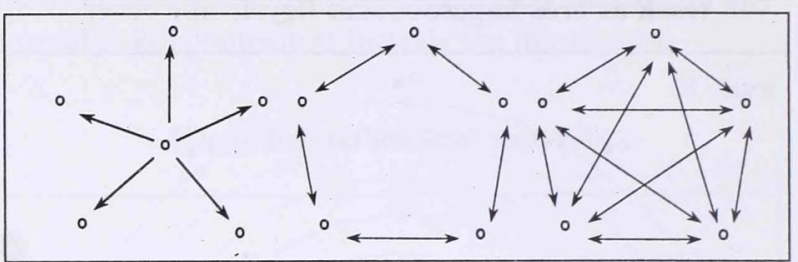

Forrás: Handy, 1999: 174. o.

csolódnak egymáshoz az egyének a kommunikációs folyamatokban. Handy három jellemző szerkezetet különböztet meg: a kerék, ahol az információkat egy központi személy osztja el, a kör, ahol az egyének meghatározott sorban kapcsolódnak egymáshoz és a háló, ahol a kommunikációban mindenki kapcsolódik minden érintetthez, így az információk közvetlenül és bármely úton továbbítódnak a résztvevők között.

A hatalomkultúrához legjobban a kerék mintájú interakciós szerkezet illeszkedik. A központi hatalom biztosításának egyik pillére az információk központi elosztása, aminek érdekében (legalábbis a formális kommunikációs :csatornákat) a vezető tartja kézben. $\mathrm{Az}$ információkat tudatosan szűrve és csoportosítva juttatja tovább az egyes érintettek felé. Ez a szervezet működésmódjával és kultúrájával nem áll ellentétben, mivel a kollektív döntéshozatal hiányában nincs szükség a szervezeti egyének jólinformáltságára. A kommunikációt a szóbeliség dominálja, nem jellemző az írásos dokumentumok, jelentések gyártása. Ez a kommunikációs szerkezet igen gyors információáramlást tesz lehetôvé, de bonyolult, nehezen átlátható és strukturálható problémáknál a központi elosztó képességei korlátozhatják a hatékony interakciók kialakulását. Másrészt a periférián állók sokszor elszigeteltnek érezhetik magukat, ami az elégedettséget és ezzel az elkötelezettséget erősen csökkentheti. ${ }^{2}$

A szerepkultúrában a kommunikációt is a szabályozottság jellemzi, a formális kommunikáció csatornáit egyértelműen meghatározzák. A rögzített „,szolgálati út" előírja az információáramlás lehetséges útjait: az információk ezen útvonalakon jutnak el a felső vezetéstől a hierarchia különböző szintjein keresztül a szervezet legalsóbb szintjeire és viszont. A kommunikációt az írásbeliség jellemzi. Jellemző a szerepkultúrára az interakciós minták közül a kör típusú szerkezet, ahol az egyének meghatározott szekvenciális rendben kapcsolódnak egymáshoz. Ebben az esetben talán szerencsésebb lenne egyfajta láncszerkezetről beszélni, mivel a kommunikációs csatornák nem zárulnak körré, 
hanem az információkat két irányban áramoltató lánccá álnak össze. Handy szerint (Handy, 1999: 175. o.) ez a kommunikációs szerkezet a leglassabb és legkevésbé rugalmas. Handy az interakció ilyen mintázatánál a koordináció hiányát emeli ki, amit azonban a szerepkultúra szabályozottsága (a hatásköri és ügyviteli előírások, a szolgálati út, a jelentések, dokumentumok elkészítésének szabályai) pótolhat.

Az ilyen bürokratikus szervezetek jellemzésében a formális kapcsolatok kapnak hangsúlyt. Azonban mint minden emberi közösségben, a bürokratikus szervezetekben is kialakulnak olyan informális kapcsolatok, csoportközi viszonyok, amelyek árnyalják a szerepkultúra működéséről felvázolt képet. Éppen az ilyen informális megoldások biztosíthatnak a szerepkultúrában bizonyos fokú rugalmasságot. Ezeket a belső informális kapcsolatokat vizsgálta Blau híres tanulmányában, amelyben egy kormányzati hivatal napi működését vizsgálta (Blau, 1963). A hivatalban az eljárási szabályok tiltották, hogy az azonos szinten dolgozók egymástól kérjenek tanácsot vagy segítséget. Ilyen esetekben is a formális ,szolgálati utat” kellett követniük a tisztviselőknek, vagyis kizárólag közvetlen főnökükhöz fordulhattak. Azonban Blau azt tapasztalta, hogy a hivatalnokok a problémáikkal nem szívesen fordulnak a főnökükhöz, részben azért is, mert a megítélése romlana így a felettese részéről, ami az előrelépési lehetőséget csökkentheti. Ehelyett a szabályokat megszegve gyakran fordultak egymáshoz. Az azonos szinten dolgozók közt erős kötődés, szolidaritás alakult ki, és létrejött egy olyan informális kommunikációs hálózat, ami megváltoztatta az interakciók mintázatát, az információáramlás csatornáit, valamint hozzájárult ahhoz, hogy a szabályokhoz képest a hivatalnokok nagyobb kezdeményezőkészséget és felelősségvállalást mutattak a munkájuk végzése során.

A feladatkultúrához pedig a fentebb említett interakciós minták közül teljes mértékben illeszkedik a hálószerkezet. Megfelelő kollektív szellemben az információ minden érintett között hatékonyan áramlik, a szükséges információk mindig eljutnak a megfelelő pontokra. Handy szerint bonyolult, nyitott problémáknál ez a kommunikációs struktúra adja a legjobb megoldást, ami köszönhetô a rugalmasságának és annak, hogy a legtöbb, a szervezetben felhalmozott tudást és képességet képes bekapcsolni a kommunikáció folyamatába. Ez akkor valósulhat meg, ha nem korlátozzák a kommunikáció rugalmasságát bürokratikus szabályok, és a tagok elkötelezetten részt vesznek a kommunikációban. Ugyanakkor ez a legidőigényesebb interakciós szerkezet. Ha sürget az idő, vagy rivalizálás van, akkor a kommunikációs háló vagy szétesik, vagy kerékké alakul át, mivel, mint más erőforrásokat, az információkat is megpróbálják központilag elosztani.

Az ilyen interakciós mintázatok feltárásának egyik igen hasznos módszere a kapcsolatháló-elemzés, amivel pontosan olyan jellemzőket vizsgálunk, amikre eme részben hivatkoztam. Tehát a kommunikációs kapcsolatoknak a feltárása a kapcsolatháló-elemzés eszközeivel alapját adhatja a szervezeti kultúra olyan jellegú jellemzésének, amit a Handy-féle tipológia is mutat.

\section{Fogalomtár ${ }^{3}$}

\section{Gráf és szociomátrix}

A kapcsolatháló-elemzésnél a vizsgált szereplők (egyének, csoportok, vállalatok stb.) közti kapcsolatokat jelenítjük meg. A kapcsolatháló vizuális megjelenítésére két módszer terjedt el, a gráf és a szociomátrix. A gráfok esetében a vizsgálat elemeit, a szereplőket pontok jelölik és a köztük lévő kapcsolatokat pedig vonalakkal vagy nyilakkal lehet megjeleníteni. A nyilak irányával lehet jelölni a kapcsolat irányát, a vastagságával pedig az erősségét. A szociomátrix esetében pedig a vizsgált elemeket a mátrix sorai és oszlopi képviselik és a köztük lévő kapcsolatok jellemzőit találhatjuk a táblázat egyes celláiban.

\section{Sürüség (density)}

A tényleges és a lehetséges kapcsolatok aránya. Azt tükrözi, hogy az adott sokaságon belül mennyire sűrú a kapcsolatok szövedéke.

\section{Mintázat}

A kapcsolatháló morfológiai jellemzője: milyen mintázatot mutat a kapcsolatok rendszere (erősen központosított centrális kapcsolatrendszer, vagy esetleg egy sűrű háló képe tükröződik), amit lehet a kapcsolatháló egészére, vagy részleteire is vizsgálni. A mintázat vizsgálatához fontos információkat adnak a sűrűség és a centralitás mutatói.

\section{Irányítottság}

Az elemzésnél az egyik fontos ismérv a kapcsolatok irányítottsága. Két alany közti kapcsolat lehet irányított, ekkor az egyik alanytól indul a kapcsolat, a másik alany pedig a kapcsolat fogadója. Az irányított kapcsolat lehet egyirányú vagy többirányú. Irányítatlan kapcsolatról akkor beszélünk, ha a két alany közti kapcsolat esetében nem lehet a kapcsolat küldőjéről és fogadójáról beszélni. Az irányítatlan kapcsolatokat a gráf pontjai közt vonalakkal ábrázoljuk. 


\section{Fok (degree)}

Egy alany kapcsolatainak a száma. Irányított kapcsolatok esetében külön vizsgáljuk a befelé irányuló kapcsolatok számát: befok (indegree), és a kifelé irányuló kapcsolatok számát: kifok (outdegree).

\section{Közeliség (closeness)}

Két alany hány lépéssel érhető el.

\section{Köztesség (betweenness)}

Két alany közti legrövidebb utak száma.

\section{Centralitás - központiság}

A kapcsolatok arányát mutatja a háló összes elemével. Többféleképpen is meghatározható, legegyszerűbb módja egy alany centralitásának mérésére az, ha összehasonlítjuk az alanyok fokát, vagyis a kapcsolatok számát. Az a szereplő, aki több kapcsolattal rendelkezik, központi helyet foglalhat el a hálózatban. Irányított kapcsolatok esetében a kapcsolatok jellege határozza meg, hogy a centralitás méréséhez a ki- vagy a befokot érdemes-e inkább tekintetbe venni. Ez a módszer azonban csak a közvetlen szomszédokra vonatkozik, csak a közvetlen kapcsolatokat veszi figyelembe. A centralitást lehet vizsgálni még a köztesség (eszerint az van centrális pozícióban, akihez a legtöbb úton lehet eljutni) és a közeliség (eszerint az van centrális pozícióban, akit átlagosan kevesebb lépéssel érhetnek el a többiek) mutatóival is. A negyedik módja a centralitás mérésének pedig az, ha a kapcsolódó elemek centralitásával súlyozzuk a kapcsolatok számát. A súlyok révén ez a módszer azt is figyelembe veszi, hogy az adott alany központi, vagy elszigetelt elemekkel van-e kapcsolatban, így pontosabb, az egész hálózatra értelmezett helyzetet mutat.

\section{Presztízs}

A befelé és kifelé irányuló kapcsolatok (befok és kifok) közti különbség tükrözi az alany presztízsét a vizsgált sokaságon belül. Minél magasabb a befok a ki-fokhoz képest, annál nagyobb presztízzsel bír az adott alany.

\section{Felhasznált irodalom}

Blau, P. M. (1963): The Dynamics of Bureaucracy, University of Chicago Press, Chicago
Borgulya Istvánné (2001): Megújuló vállalti kultúrák - Átalakuló vállalati kommunikáció, Vezetéstudomány, 2001. 7-8. szám 33-40.o.

Dekker, A. H. (2001a): A Category - Teoretic Approach to Social Network Analysis, C3 Research Centre, Canberra, in: Teorethical Computer Science 2001/61. http://www.elsevier.nl/ locate/entcs/volume61.htm, 2002. 05. 10-én

Dekker, A. H. (2001b): Visualisation of Social Networks Using CAVALIER. In Proc. Australian Symposium on Information Visualisation, Sydney, Australia. Conferences in Research and Practice in Information Technology. http://cript.com/ confpapers/CRPITV9Dekker.pdf, 2002. 05. 10-én

Faust, K. - Wassermann, S. (1994): Social Network Analysis: Methods and Applications. Cambridge University Press

Granovetter, M. (1985): Economic Action and Social Structure: The Problem of Embeddednes. American Journal of Sociology, 91, p. 481-510.

Granovetter, M. (1996): A gazdasági intézmények társadalmi megformálása: a beágyazottság problémája. In: A gazdasági élet szociológiája (szerk: Lengyel György - Szántó Zoltán), Aula, Budapest

Handy, B. Charles (1999): Understanding Organizations, Penguin Books, London

Lazarsfeld, P. M. - Menzel, H. (1961): On the Relation between Individual and Collective Properties, in: A Social Reader on Complex Organisations (szerk: Etzioni, A.), London

Letenyei László (1993): A falusi társadalom rejtett kapcsolatai, http://www.bke.hu/ socnet/falukut/falunet.htm, 2002. 06. 12én

Letenyei László (2000): Regionális társadalmi hálózatok - A kapcsolatháló elemzés alkalmazásának lehetőségei a reginális fejlesztésben,

Falu - Város - Régió, 2000/6. 21-25.o.

Mintzberg, Henry - Heyden, Ludo Van Der (2000): Organigráfok a vállalatok valódi mủködésének ábrázolása, Harvard Business Manager, 2000/4. 6-13.o.

Polányi Károly (1976): Az archaikus társadalom és a gazdasági szemlélet, Gondolat, Budapest

Vedres Balázs (1997): Bank és hatalom - A bankok helye a magyar nagyvállalatok kapcsolathálójában. http://www.bke.hu/ socnet/bankhatm/cegnetsz.html, 2002: 06. 12-én

\section{Lábjegyzetek}

${ }^{1}$ Az elemzéshez a Cyram Netminer hálózatelemző szoftvert használtam, aminek egy ingyenes (de csak kisebb sokaságok vizsgálatára használható) változata elérhető a következő internetcímen: http://www.netminer.com/NetMiner/home_01.jsp

${ }^{2}$ Borgulya Istvánné ilyen irányú kutatásában kiemeli, hogy Magyarországon gyakran lehet találkozni a struktúra, kultúra és kommunikáció ilyen k̨onfigurációjával (Borgulya, 2001)

${ }^{3}$ A kapcsolatháló elemzésnél használt alapfogalmakat Katherine Faust és Stanley Wassermann, valamint Vedres Balázs tanulmányaira alapozva foglaltam össze (Faust - Wassermann, 1994; Vedres, 1997) 